\title{
The New England
}

\section{Journal of Medicine}

rOLUME 214

MAY 14, 1936

NUMBER 20

\section{THE HYPOPHYSIS AND METABOLISM*}

BY BERNARDO A. HOUSSAY, M.D.\|

$\mathbf{F}$ UNCTIONALLY the most important of the four parts of the pituitary is the chromophile (principal, distal or anterior**) lobe. Its functions may be classified provisionally as (1) morphogenetic (growth and metamorphosis), (2) endocrine stimulating and regulating (development and maintenance of the gonads, thyroids, adrenal cortex, parathyroids, thymus $\dagger$ etc.), (3) sexual and reproductive (development and maintenance of the gonads and their functions, the sexual characteristics, breasts and milk secretion, etc.), (4) metabolic (either directly or indirectly by its action on other endocrine glands). The sexual functions are really endocrine and belong in class 2, but they have been placed in a separate group because of their special importance. This classificationt is simple and elastic, but obviously it is not perfect.

The anterior pituitary lobe, because of its actions on growth, metabolism $\S$ and the endocrine glands, is necessary for the development and maintenance of the individual in a normal state: because of its sexual and reproductive actions it is necessary for the maintenance of the species. It is the central and directing organ in the endocrine constellation, since its presence is required for the development and maintenance of the other glands. In some cases the latter also have an influence on the pituitary.

The posterior or neuro-intermediate lobe provides extracts of marked pharmacological activity, but its functional rôle is inferior to that of the principal lobe. Its functions of melanophore dilatation, maintenance of the capillary tone and arterial blood pressure, and regulation of water elimination through the kidneys are well known in amphibians, but the vasotonic, renal and oxytocic functions, have not yet been proved with certainty in mammals and its rôle has yet to be precisely established.

To be certain of the existence of a pituitary function it is not enough to observe the pharma-

\footnotetext{
*This and the following paper comprise the second and third lectures in the Dunham Lectureship Series delivered at the Harvard Medical School in November, 1935. Since they deal with related subjects, they are published together. The refernces for both papers appear on page 982 .

**In some species, e.g., amphibia, it is posterior.

tIt may or may not be an endocrine gland.

$¥$ This is a classification according to functions, not hormones, the number of which is not taken into account.

\$In the amphibia, which I have studied, lack of the principal lobe produces progressive metabolic disturbances, accompanied by neuromuscular asthenia ending in death. In mammals, death due to hypoglycemia or cachexia may be observed.

HHoussay, Bernardo A.-Professor of Physiology, Faculty of Medical Sciences, University of Buenos Aires, 1919-. For record and address of author see "This Week's Issue," page 946, issue
} or May 7. cological action of an extract. The following conditions must be fulfilled: (1) a deficiency must be produced by extirpation of the gland; (2) this deficiency must be compensated for by graft, implantation or extract of the gland (or of the part under observation); (3) an excess of extract must cause phenomena* opposite to those of insufficiency. Since the pituitary is the central organ in the endocrine system, certain of its actions are due to its influence on other glands. This is shown by: (1) extirpation of any gland under consideration produces a similar insufficiency, but greater than that produced by hypophysectomy; (2) neither correction of the insufficiency nor hyperfunction is obtained by administration of pituitary extract if the said gland has been previously removed.

Until recently attention was mainly fixed on the growth, sexual and endocrine functions of the pituitary but in my opinion the metabolic functions are of great importance, as in the case of the other endocrine glands.

In this lecture I cannot attempt to describe all the extant knowledge concerning the pituitary and metabolism. I must content myself with mentioning the work contributed by my Institute which is very incompletely known, owing to difficulties of language and to the unfortunate tendency in almost all countries for workers to confine themselves to the literature in their own language. This of course, as is shown by the generous invitation given me, does not apply to Harvard University.

We have made a detailed study in one species, the dog, which permits us to correlate the numerous data we have obtained in various species with each other.

BASAL METABOLISM AND SPECIFIC DYNAMIC ACTION

The action of the anterior pituitary on basal metabolism is essentially through the thyroid. Hypophysectomy causes an atrophy of the thyroid epithelium (whose cells become flattened) and provokes hypothyroidism with lowering of the metabolism. Of the twenty-seven hypophysectomized dogs in which the basal metabolism

*To affirm with certainty the existence of a pituitary function in man the following facts must be established. (1) Anatomicoclinico-functional phenomena (acromegaly, basophilism, hypopituitarism, etc.). (2) Removal or destruction of the gland (surgery or $x$-rays, etc.) must moderate the symptoms of hyperfunction or produce the syndrome of hypofunction. (3) Properly prepared pituitary extracts must compensate the deficiency and when given in excess should produce symptoms similar to the pathological hyperfunction. Without these concurring observations it is not possible to affirm the existence of a suspected function. Isolated pharmacological data are insufficient. 
has been measured and that have been published up to date, twenty-two were prepared and studied in our Institute. ${ }^{1,2,48,49,50,53,54,55,117}$ The metabolism was diminished (average 16 per cent) in all except three, in which there was no decrease. These three dogs were the only ones which had a high columnar epithelium in the thyroid.

In the rat we found, like Collip, an average decrease of 24 per cent. In the toad no metabolic decrease occurred except when there was advanced asthenia.*

In hypophysectomized dogs there is thyroid insufficiency but not athyroidism because if the thyroid gland is removed there is a further metabolic decrease reaching to 24 per cent. On the other hand the metabolic decrease in thyroidectomized animals (average 24 per cent) is not modified by hypophysectomy.

Tuberal lesions caused a decrease in the metabolism in eleven of the twenty-two dogs studied up to date (eleven by Grafe and his collaborators, eleven in our Institute by Mazzocco $;^{117}$ Solari $\left.^{133}\right)$. It is probable that in these cases, as in others, the tuberal lesion diminishes or inhibits the thyrotropic action of the anterior pituitary, but in several animals there was no atrophy of the thyroid epithelium. It is also possible that the tuber has a direct action on the pituitary or on other mechanisms.

A rise in metabolism occurs on injection of anterior pituitary extracts which have a thyrotropic action, the degree of rise depending on the species studied. $\dagger$ In the experiments of Artundo and Solari ${ }^{4}$ and Houssay and Artundo ${ }^{53,54,55}$ in both normal or hypophysectomized dogs there was a metabolic increase of between 28 and 62 per cent, accompanied by hyperactivity of the thyroid (high epithelium, liquefaction and reabsorption of colloid) and by signs of hyperfunction (tachycardia, polypnea, slight rise in temperature, loss of weight, polyuria). These phenomena do not occur if the injected animal is already thyroidectomized $\neq$, although some animals have a slight metabolic increase and others a diminution. ${ }^{51,52,54}$

We have not studied the habituation that is observed with prolonged treatment. In these cases a gradual decrease in metabolism which falls below the normal is seen and an antithyrotropic substance appears in the blood, (Anderson and Collip, Collip, etc.). In this connection it must be remembered that other anterior pituitary extracts depress metabolism. (Falta, Verzar, Magistris, etc.)

The specific dynamic action in twenty hypoph-

*In other batrachians a decrease has been observed. Observations at different temperatures should be repeated.

tBiasotti, by nasal insufflation of the acetone extracted powder of anterior pituitary lobe in some human cases, obtained an increase in basal metabolism and polyuria; in others this result was not obtained.

Caro must be taken to verify that only the parathyroids remain and that no thyroid tissue has been left. ysectomized dogs was found to be equal to that seen in normal animals. ${ }^{1,2,55,117 *}$ There is a slight decrease in the specific dynamic action after thyroidectomy, which is more pronounced if the pituitary is also removed. ${ }^{55}$

In conclusion: the anterior pituitary has an indirect tonic action on basal metabolism, through its influence on the development and maintenance of the thyroid gland.

\section{WATER METABOLISM}

It is impossible even to mention all the complex problems presented by the physiological and pharmacological actions of the pituitary on different aspects of water metabolism, so I will confine myself almost exclusively to the results of work done in our Institute.

Hypophysectomy almost always causes an intense polyuriat in dogs, rats and toads within a few hours of operation. This polyuria is transient in the great majority of dogs, and the rate of formation and the composition of the urine return to normal very soon, ${ }^{88}$ possibly because the tuberal part remains. From the time of recovery from the initial polyuric stage, water administered is eliminated either with slight retardation ${ }^{81,82,83}$ or else normally. (Reforzo, unpublished results.)

Lesions of the tuber cinereum produce an intense polyuria which is frequently transient but

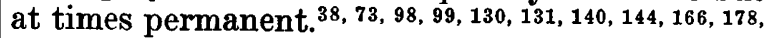
179, 181, 194, 254, 313, 421, etc. This phenomenon seen by Aschner ${ }^{140}$ and amply studied by Camus and Roussy ${ }^{178,179}$ has been confirmed many times in our Institute. - Polyuria is observed only when the region in the neighborhood of the tuber cinereum is damaged. It does not occur if the lesion is produced outside this zone, as, for example, in the base (Houssay and collaborators, 1915-20) or in the dorsal surface of the brain. ${ }^{100}$ (Fig. 1.) The polyuria occurs even when the pituitary appears to be histologically normal. This tuberal polyuria can be obtained experimentally in dogs, ${ }^{38,72,73,98,99,130,131}$ toads, ${ }^{80,124}$ sometimes in rabbits, ${ }^{33}$ rats, ${ }^{369}$ pigeons $^{371,372}$ and is also seen in man in cases with pathological changes. ${ }^{167}, 306,307,313$, etc.

The tuberal polyuria oceurs in dogs with previously denervated kidneys ${ }^{72,99,144,175}$ or after the splanchnics have been cut and the lumbar sympathetic chain extirpated ${ }^{131}$ and also when the liver and pancreas have been denervated. (Rubio. ${ }^{131}$ )

There may be lesions in various of the hypothalamic nuclei in animals suffering from polyuria. but the only constant lesions are those of the tuberal nuclei. (Ramirez Corria, ${ }^{125}$ confirming Camus, Gournay and Le Grand, ${ }^{177}$ Gournay. ${ }^{248}$ )

*This statement is made without reference to what may occur in man, since we have not studied the latter species.

tConfirmed by numerous workers since it was discovered by Vassale and Sacchi426 in the dog. 
Polyuria usually precedes polydipsia and is its absence causes polyuria. When blood of a seen even if the animal is deprived of water. heart-lung-kidney preparation is diffused The animals suffering from polyuria may be through the head of a dog it causes a decrease distinguished from the controls in water depri- in polyuria and an increase in the elimination vation experiments by the fact that the diuresis of chlorides. Perfusion through the pelvis and is more prolonged, the density of the urine in- hind legs has no effect. If, however, the pituicreases later and the blood becomes more con- tary has been previously extirpated, perfusion centrated. through the head also fails to check the poly-

Posterior lobe extract usually has an oliguric uria. ${ }^{28}$ Hypophysectomy in a few hours causes
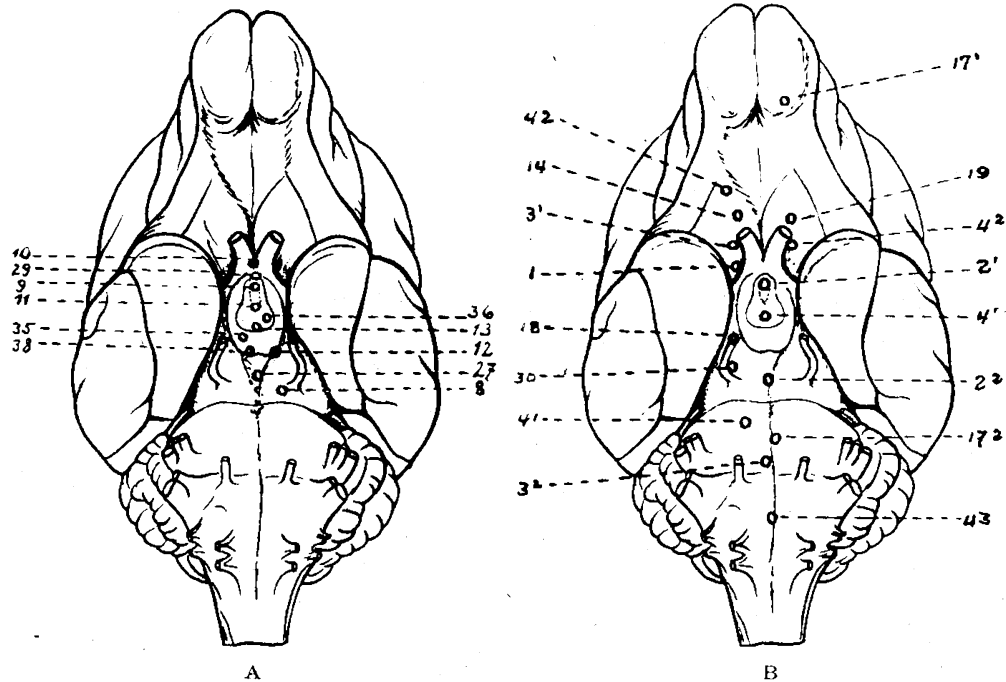

A

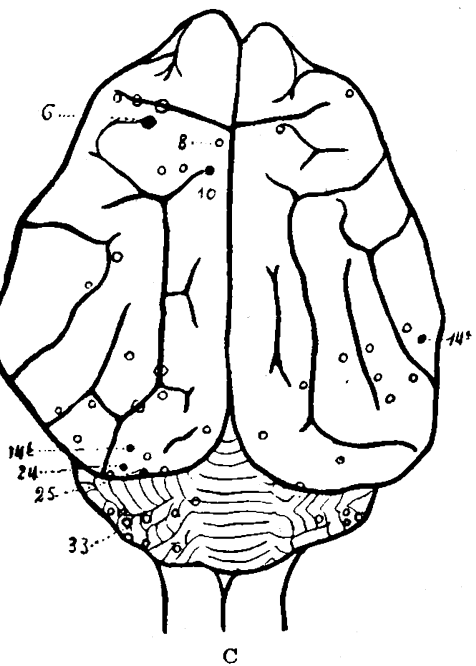

FIG. 1.

Drawings of a dog's brain showing the positions of piquares which resulted in diabetes insipidus, $A$, and of those which did not alter the water metabolism, B and C.

action in normal animals ${ }^{41,72,89,144,175}$ and also in animals in which the kidneys have been denervated $^{79,383}$ In certain conditions, however, it acts as a diuretic. ${ }^{41,384,385}$

Posterior pituitary lobe extract diminishes or counteracts experimental or pathological polyuria insipida but its action is only transient, particularly if the polyuria is very intense. (Houssay and Hug. ${ }^{81}, 82,83$ )

The experiments of Verney ${ }^{428}$ and Brull ${ }^{169,170}$ favor the theory that a pituitary secretion physiologically modifies normal diuresis and that polyuria and fall in chloride excretion which pituitrin corrects. ${ }^{169}$ If the blood yessels of a kidney are united to those of a polyuric dog, it secretes dilute urine, but if the irrigation is changed for that of a dog with intact pituitary the kidney secretes more concentrated urine. ${ }^{170,188}$

It is therefore probable that tuberal polyuria is to be attributed in great part to an inhibition of the kidney-regulating secretion of the posterior pituitary.

The results we have obtained with toads in 
our Institute are of great interest. Polyuria may be produced in toads of the species $B u f b$ arenarum Hensell, as was observed by Houssay, Giusti, and Goñalons. ${ }^{80}$ This was carefully analyzed by Pasqualini (work being published) and shown to be due to insufficiency of the neuro-intermediate lobe affecting especially the renal function. In toads polyuria occurs in 70 per cent of total hypophysectomies, in 33 per cent where the principal lobe is extirpated,* and in 20 per cent where there are diencephalic lesions (of the infundibular lobe or of the pars basilis lamina terminalis). In the first two groups it is immediate, progressive, intense and persistent; in those with diencephalic lesions the polyuria is transient.

The renal origin of the polyuria, through a deficiency of neuro-intermediate secretion, is suggested by the following facts: 1 . The polyuria persists even when the animal is deprived of water until urine secretion ceases. 2. From the moment the diuresis ceases the animal loses weight by evaporation until the final rate of evaporation equals that in controls. 3. Water injected into the abdomen is eliminated more rapidly in the hypophysectomized animal. 4. If the ureters are ligated, cutaneous absorption of water is equal both in hypophysectomized and control animals. 5. The neuro-intermediate lobe and pitressin will stop the polyuria. With very large doses oliguria or anuria may be produced. 6. These results may be observed in animals deprived of water and with or without injection of water into the peritoneum. 7 . Large doses of neuro-intermediate lobe extract have another action completely apart from the renal. This consists in the production of edema, with a great increase in weight, in both normal and nephrectomized animals. ${ }^{5,} 171,262,410,411,412$, etc. If the animal is placed in a hypertonic solution there is no such effect. Pitressin is more active than pitocin. Besides the renal action in these cases there is an increase in the permeabil-

*In this case probably owing to hypofunction of the remaining neuro-intermediate lobe. ity of the skin to water. ${ }^{121}$ For the sake of brevity I will omit further details.

Thyrotropic anterior pituitary lobe extract causes polyuria in the dog by its thyroid stimulating action, but does not do so if the thyroid has been previously extirpated.8,150 It is not modified by castration, section of the splanchnics, etc.

\section{MINERAL METABOLISM}

Marenzi and Gerschman have shown that the blood plasma of hypophysectomized dogs has a diminished amount of potassium. ${ }^{88,112,113}$ In eighteen dogs the average was $16.3 \mathrm{mgm}$. per 100 ce. On the other hand the calcium is nor$\mathrm{mal}^{34,35,88,112,116} 11.6 \mathrm{mgm}$. average in fortyseven dogs, and so is the magnesium, $2.03 \mathrm{mgm}$. in twenty dogs. No significant alterations are found in chlorine, phosphorus, sodium and $\mathrm{CO}_{2}$. (Table 1.)

The decrease in the potassium of the plasma is not seen in thyroidectomized or pancreatectomized animals. It occurs in some dogs with tuberal lesions (average $17.2 \mathrm{mgm}$. in eight animals) probably due to a certain degree of pituitary hypofunction.

Extirpation of the pituitary and pancreas in the same dogs causes the modifications found in both hypophysectomized (decrease in potassium) and pancreatectomized (decrease in calcium, chlorides and sodium) animals. The alkali reserve, however, is only a little lowered and acidosis and ketonuria are very slight (attenuation of diabetes due to pituitary insufficiency). ${ }^{113}$

Alkaline anterior pituitary extract (in large doses intraperitoneally) causes an abnormal rise in the alkali reserve, and in phosphates, calcium, magnesium and potassium.* The chlorides and sodium are lowered, the latter to a less marked degree. (Table 1.) These results are not due to hyperthyroidism since, except for the hypercalcemia, they are observed in thyroidec-

*Potassium returns to normal in the hypophysectomized animals, but is not modified in the controls. It should also be remembered that diabetes develops under this treatment.

\section{TABLE 1}

Muneral Contents of the Blood Plasma of Dogs Under Different Experimental Conditions

\begin{tabular}{|c|c|c|c|c|c|c|c|c|c|}
\hline \multirow{2}{*}{$\begin{array}{l}\text { Operation } \\
\text { and Number } \\
\text { of Dogs }\end{array}$} & \multirow{2}{*}{$\begin{array}{c}\text { Blood } \\
\text { Sugar } \\
\text { in Gm. } \\
\text { per } 100 \text { cc. }\end{array}$} & \multirow{2}{*}{$\begin{array}{l}\text { Red } \\
\text { Cell } \\
\text { Vol- } \\
\text { ume } \\
\end{array}$} & \multirow{2}{*}{$\begin{array}{l}\text { Total } \\
\mathrm{CO}_{2} \\
\text { Vol. } \\
\% \\
\end{array}$} & \multicolumn{2}{|c|}{ Mgm. per } & \multicolumn{2}{|c|}{$\begin{array}{l}\text { Cent of Plasm } \\
- \text { Substances }\end{array}$} & \multicolumn{2}{|c|}{ Inorganic } \\
\hline & & & & $\mathrm{Cl}$. & $\mathbf{P}$ & $\mathbf{K}$ & Na. & Ca. & Mg. \\
\hline Normal dogs (11).... & 0.095 & 43.9 & 48.2 & 389 & 4.18 & 18.9 & 385 & 11.2 & 2.08 \\
\hline Hypophysectomized dogs (9)............... & 0.090 & 42.5 & 47 & 386 & 3.8 & 15 & 396 & 11.2 & 1.89 \\
\hline Tuber cinereum lesion: dogs (3)... & - & 51.9 & 48.3 & 389 & 3.77 & 17.1 & 395 & 11 & 1.74 \\
\hline $\begin{array}{l}\text { Thyroidectomized dogs }(6) \\
\text { Normal dogs injected with glandu-........... }\end{array}$ & 0.109 & 45.9 & 49.6 & 381 & 4.14 & 18.7 & 379 & 10.2 & 1.85 \\
\hline $\begin{array}{l}\text { lar lobe extract (6)......................... } \\
\text { Normal dogs injected with organ }\end{array}$ & 0.266 & 42.3 & 53.8 & 325 & 7.88 & 18.8 & 345 & 12.8 & 2.34 \\
\hline extracts (2) & 0.135 & 46.2 & 48.1 & 368 & 3. & 17 & & 11.1 & 1.83 \\
\hline $\begin{array}{l}\text { Pancreatectomized dogs (2) } \\
\text { Hypophysectomized and pancrea- }\end{array}$ & & 34.0 & 31. & 356 & 5.88 & 18.5 & 352 & 8.3 & 1.69 \\
\hline tectomized dogs (3) & 一 & 33.0 & 54.1 & 296 & 4.18 & 15.2 & 323 & 8.5 & 1.90 \\
\hline
\end{tabular}


tomized animals, nor have they a nonspecific effect since they are not produced by extracts of kidney and muscle. The rise in calcium is not seen in thyroparathyroidectomized animals, that is to say, when the parathyroids are missing.

The urinary elimination of phosphates is almost the same in hypophysectomized dogs as in normal animals when on a meat diet, but it is diminished more than in the normals during total fasting and the decrease is greater still when there is protein fasting. ${ }^{34,35}$ There is a marked decrease of phosphatase in the serum of hypophysectomized dogs. (Martinez, unpublished work.)

\section{IODINE METABOLISM}

In more than twenty-five papers, we have published the studies made in our Institute on the relation between the thyroid and the pituitary. The anterior pituitary lobe controls the development and the maintenance of the anatomical structure and functional activity of the thyroid. Extirpation of the pituitary produces atrophy and hypofunction of the thyroid while an excess of the thyrotropic substance of the anterior pituitary causes morphologic and functional overactivity of the thyroid gland.

Hypophysectomy does not modify or only slightly raises the total iodine in the thyroid but the percentage content of iodine is manifestly raised. ${ }^{67}$ (Table 2 and fig. 2.) The iodine in

\section{TABLE 2}

Iodine Content of the Thyroids of Dogs Under DifFerent Experimental Conditions

(Mean Weight $9 \mathrm{Kgm}$.)

\begin{tabular}{|c|c|c|c|c|}
\hline $\begin{array}{c}\text { Operation } \\
\text { and } \\
\text { Number } \\
\text { of Dogs }\end{array}$ & $\begin{array}{c}\text { Total } \\
\text { Iodine } \\
\text { Mgm. }\end{array}$ & $\begin{array}{c}\text { Iodine } \\
\text { Mgm. } \\
\text { per } \\
\text { Cent }\end{array}$ & $\begin{array}{l}\text { Prob- } \\
\text { able } \\
\text { Error } \\
\quad \pm\end{array}$ & $\begin{array}{c}\text { Varia- } \\
\text { tion \% } \\
\text { of } \\
\text { Normal }\end{array}$ \\
\hline 32 Normals & 0.95 & 63 & 3.7 & 0 \\
\hline $\begin{array}{l}\text { 17- Hypophysectomized } \\
\text { during first } \\
\text { month }\end{array}$ & - & 85 & 6.5 & - \\
\hline $\begin{array}{l}\text { 14-Hypophysectomized, } \\
1 \text { to } 5 \text { months } \\
\text { later } \\
\text { 10-Normals, injected } \\
\text { with glandular } \\
\text { lobe extract }\end{array}$ & 1.12 & 100 & 7.7 & +58 \\
\hline
\end{tabular}

the blood rises considerably during the first few days after operation and later decreases over a period of two to four weeks; after forty-five to sixty days it is always normal and remains so afterwards. (Fig. 3.) We have been able to add further results to those already published ${ }^{89}$ and have so far studied a total of sixty-one hypophysectomized dogs, thirty-seven controls, eleven with lesions of the tuber, six without the posterior lobe, thirteen craniotomized.* Lesions of the tubert and extirpation of the posterior lobe produce a lower initial rise in the blood iodine which is only transient. Extirpation of the thyroid causes an initial slight increase followed by a definite decrease to considerably below the normal level. We have attributed the initial rise in the blood iodine to the slight hyperthyroidism which frequently occurs during the first days after hypophysectomy. We did not obtain this initial increase in the blood

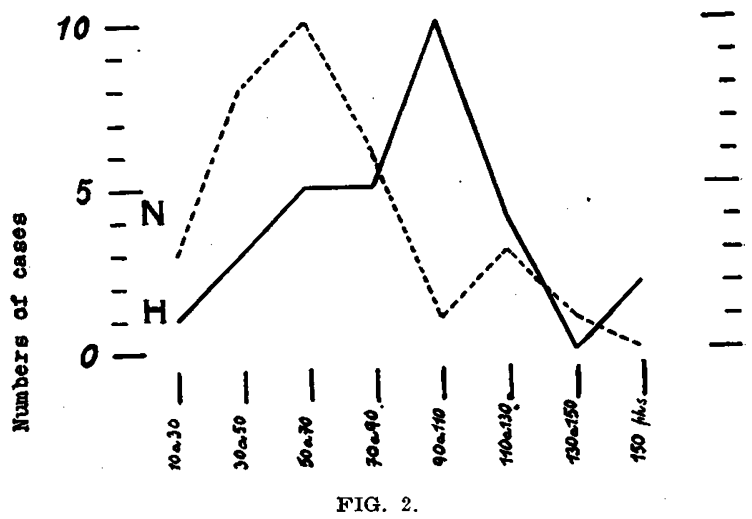

Distribution curves of normal (dotted line) and hypophysectomized (solid line) dogs on the basis of the concentration of iodine in the thyroid.

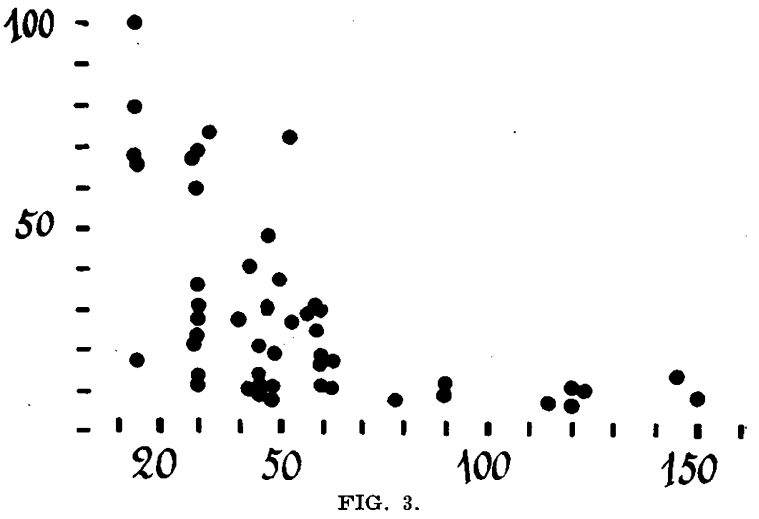

Chart showing the early rise and later fall of the blood iodine following hypophysectomy.

Abscissae-Days after hypophysectomy.

Ordinates-Mgm. iodine per $100 \mathrm{cc}$. blood.

iodine after hypophysectomy in two previously thyroidectomized dogs, which further supports our interpretation. This does not, however, explain satisfactorily why it should persist even when the thyroid is undergoing atrophy.t

*The average blood iodine in the second series was $13 \mathrm{mgm}$ p.c.

†Sturm 410 did not find an increase when the tuber was inured.

iSturm ${ }^{418}$ has confirmed the existence of an initial hyperiodemia, but he found it to be transient and accompanied by hyperioduria. He believes that the hypophysis stores iodine, sending it to the intermediate brain (rich in idine a ine, to 5 it to the intermediate brain (rich in iodine according o Schittenhelm and Eisler, ${ }^{38}$ and Sturm and Schneeberg ${ }^{118}$ ) which in its turn has a direct influence on the thyroid secretion and an indirect one by means of the thyrotropic hormone of the anterior pituitary. Some of his arguments are not valid, e.g., that the hypophysis is specially rich in iodine (as has been proved by Ruff); besides he is neither the first, nor the only worker to have determined the iodine content of the pituitary.153 185208253275336357378399307405407417430 etc. 
Anterior pituitary lobe extract with thyrotropic action causes a marked decrease in the total iodine of the thyroid (alcohol insoluble and thyroxine iodine) ${ }^{90,91,185,230,231,249,250,318,391 \text {, etc. }}$ and prevents an increase after unilateral thyroidectomy.90 (Table 2.) The blood iodine, (total and alcohol insoluble), rises considerably

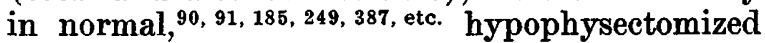
or unilaterally thyroidectomized dogs with.this treatment. ${ }^{91}$ This hyperiodemia is due to the hyperthyroidism produced, since it is not obtained if dogs with total thyroidectomy are injected. ${ }^{90,91}$ The last-mentioned animals usually present a decrease in blood iodine (due possibly to excessive elimination or greater fixation).*

The action of the anterior pituitary on the thyroid iodine and blood iodine is undeniable but it is impossible to tell whether the gland has a specific action, either direct or indirect, apart from its effect on the thyroid.

*This suggests the possibility of another action of the extract on blood iodine, opposed to the effect of the thyrotropic hormone.

\section{PROTEIN METABOLISM}

The pituitary gland is an important regulator of the endogenous protein metabolism which it stimulates, whereas it has little influence on the exogenous protein metabolism. It also takes part in the formation of sugar from protein.

On a meat diet or the same mixed diet, hypophysectomized animals eliminate the same quantity of nitrogen per $\mathrm{Kg}$. per day, as the controls. ${ }^{15-24,56-60,140}$ (Table 3.) However, during the first six to seven hours after food their urinary excretion is less, with compensatory greater excretion during the remaining seventeen to eighteen hours. ${ }^{15-21}$ If glycine is injected the curve showing its disappearance from the blood is more gradual than in the controls. ${ }^{126}$ There seems to be a slower fixation or catabolism of amino-acids.

When fasting, hypophysectomized $\operatorname{dog} s^{15-21}$ and toads ${ }^{22,23}$ only eliminate two-thirds of the quantity of nitrogen excreted by the controls. On a fat and carbohydrate diet which is protein free (i.e., protein fasting), the decrease in

TABLE 3

Nitrogen Excretion of Dogs, Toads and Rats

Recorded in Grams Nitrogen per Kilogram Body Weight per Diem

$\begin{array}{cccc}\begin{array}{c}\text { Hypo- } \\ \text { physec- } \\ \text { tomized }\end{array} & \begin{array}{c}\text { Lesion } \\ \text { of } \\ \text { Tuber } \\ \text { Cinereum }\end{array} & \text { Normals } & \begin{array}{c}\text { Per Cent of } \\ \text { Decrease of } \\ \text { Hypophysec- } \\ \text { tomized } \\ \text { Compared } \\ \text { with Normals }\end{array} \\ & & & \end{array}$

Meat Diet

Houssay and Biasotti, 1930

Braier, 1931

“ 1933

“ 1933

Total Fasting

10 days Braier, 1931

Nitrogen Free Diet

4th day Braier, 1931.

$$
1933
$$

Total fasting 2nd day Braier, 1931

Total fasting 3rd day, B. coli vaccine Braier, 1931

Fasting and Phlorhizin

Mean of 6 days. Houssay, Biasotti, 1931.

Mean of 6 days Houssay, Biasotti, 1932

Minimum protein balance with fat and starch diet Braier, 1931

Total Fasting

Braier, 1933

Complete Diet

Braier, 1935.

Braier, Morea, 1935.

Nitrogen Free Diet

Braier, 1935.

Braier, Morea, 1935

Dogs

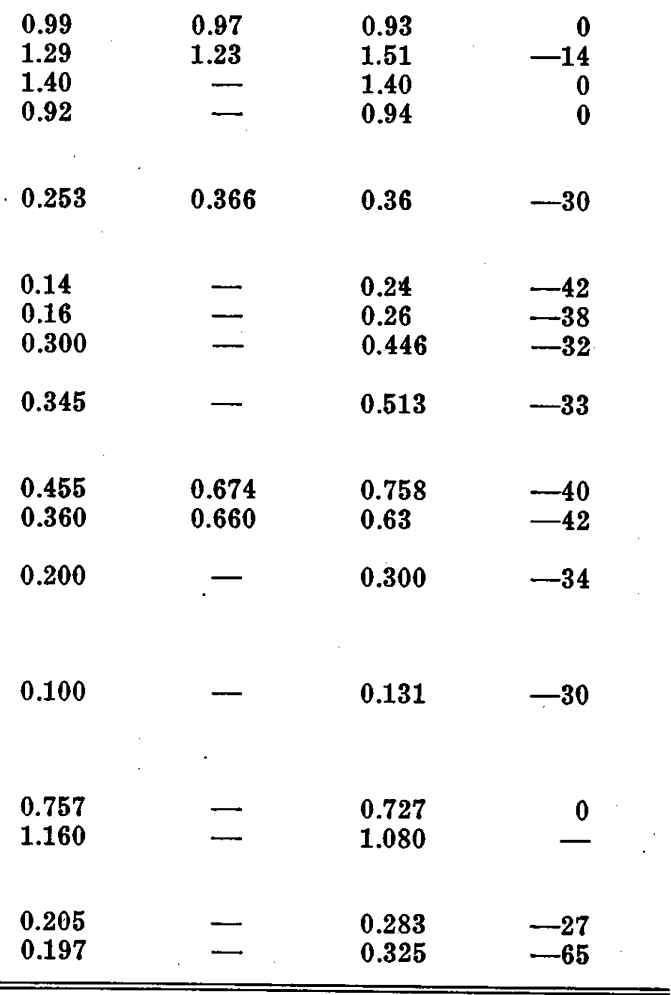


catabolism is even more marked in $\operatorname{dogs}^{15-23}$ and rats. ${ }^{24}$ With this diet only $0.18-0.20 \mathrm{Gm}$. of pro. tein per $\mathrm{Kg}$. per day is necessary to maintain the nitrogencus equilibrium in hypophysectomized animals whereas the controls require $0.30 \mathrm{Gm}$.

Since Folin's work, creatinine excretion is considered as the index of endogenous catabolism. This is slightly diminished in hypophysectomized dogs when on a meat $\operatorname{diet}^{15-21}$ and very slightly altered in hypophysectomized rats. ${ }^{24}$ But during total fasting or protein fasting there is a decrease of thirty to forty per cent in both species. (Fig. 4 and table 4 .)

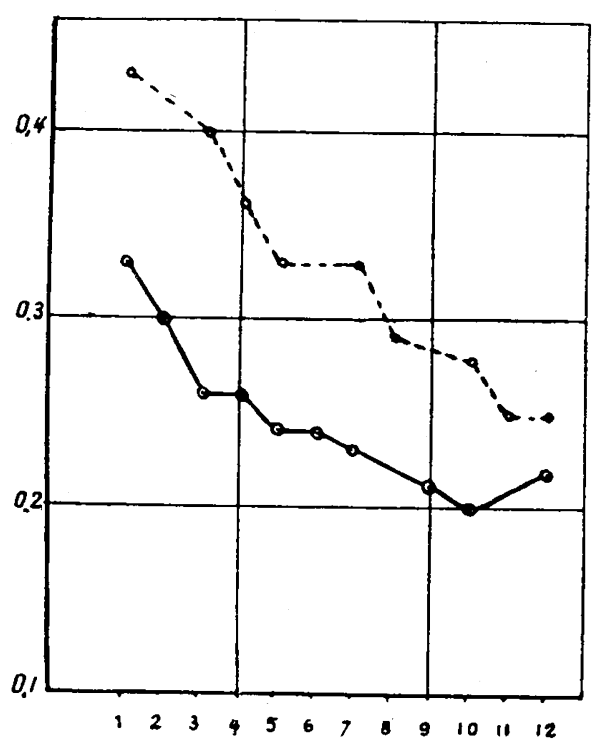

A the expense of protein during diabetes is extremely diminished.

The change in the endogenous protein metabolism cannot be due to the simple operative trauma or to a superficial lesion of the tuber, since it is not observed in craniotomized animals or in those without the posterior lobe or with injury of the tuber (galvanocauterization of 3-5 $\mathrm{mm}$. in depth and width, from the pituitary stalk to behind the mammillary bodies).

Implantation of the principal pituitary lobe causes an increase in the nitrogen excretion in

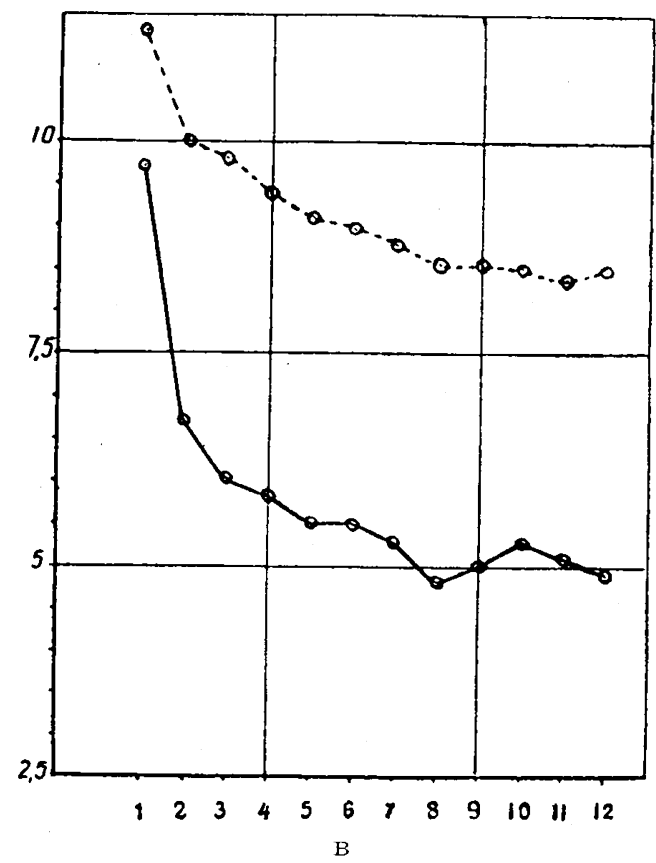

FIG. 4.

Average urinary excretion of $A$. Nitrogen and $B$ Creatinine of normal and hypophysectomized dogs (broken and solid lines respectively), during fasting.

Abscissae-Time of fasting in days.

Ordinates-A. Gm. N per Kgm. body weight per diem.

B. Mgm. Creatinine per Kgm. body weight per diem.

This lowered consumption of endogenous proteins is seen particularly and in a marked form in hypophysectomized animals suffering from pancreatic diabetes, ${ }^{56-60}$ phlorhizin diabetes, ${ }^{56-62}$ (table 5) or avitaminosis $\mathrm{B}$ and also after the injection of coli vaccine. ${ }^{15-21}$

In all these cases, and also in simple or protein fasting, the loss of weight of the hypophysectomized animals is on an average less than of the controls. They are also able to survive longer if they are not killed by a concurrent attack of hypoglycemia.

The lowered protein catabolism cannot be explained by hypothyroidism because, although thyroidectomized dogs have a decreased nitrogen excretion in simple or protein fasting, when there is need of large protein destruction (e.g., in pancreatic or phlorhizin diabetes) this is as exaggerated as in the controls, whereas the increase is very small in hypophysectomized animals. In the latter the formation of sugar at fasting hypophysectomized toads. ${ }^{22}$ Injection of thyrotropic extract of the anterior pituitary lobe causes an increase in the nitrogen excretion of normal or hypophysectomized rats during protein fasting for the first few days (Braier and Morea, unpublished) and slightly increases the protein catabolism in dogs. ${ }^{68}$ We have not yet verified the duration of this action or whether it occurs by way of the thyroid.

The metabolism of nucleoproteins has been studied by Braier ${ }^{22,23}$ in hypophysectomized dogs and by Braier and Morea (unpublished data) in hypophysectomized rats.* In both species the hypophysectomized animals eliminate less uric acid and purin bases but more allantoin, whether on ordinary diet or protein fasting. But the total sum of the three quantities is equal to that in the controls. (Table 6.)

*According to Falta and Nowaczynski225 in seven out of eight acromegalics there was an increase in the endogenous uric actd cf. $203368388420 \quad$ Schittenhelm and Harpuder 388 found a normal 


\section{PLASMA PROTEINS AND NONPROTEIN NITROGEN}

In the plasma of twelve hypophysectomized dogs, Goldberg ${ }^{37}$ found an increase in the globulins (54 per cent) and in the viscosity (inconstant), but a decrease in the albumins (22 per cent) and in the $A: G$ ratio (from 1.79 to 1.01 ). These modifications are identical with those seen in hypothyroidism.

Alkaline anterior pituitary extract, given in-

\section{PHOSPHOCREATIN}

When asthenia is well developed in the hypophysectomized toad (or in the toad after removal of only the glandular lobe) the phosphocreatin phosphorus in muscle diminishes in 33 per cent of the cases. The injection of glandular lobe extract or of mammalian anterior lobe extract brings it back to normal values. ${ }^{104,105}$

TABLE 4

Urinary Creatinine in Mgm. Per Kgm. Per Diem

\begin{tabular}{|c|c|c|c|}
\hline $\begin{array}{l}\text { Hypoph- } \\
\text { ysec- } \\
\text { tomized }\end{array}$ & $\begin{array}{c}\text { Lesion } \\
\text { of } \\
\text { Tuber } \\
\text { Cinereum }\end{array}$ & Normals & $\begin{array}{l}\text { Per Cent of } \\
\text { Decrease of } \\
\text { Hypophysec- } \\
\text { tomized } \\
\text { Animals } \\
\text { Compared } \\
\text { with Normals }\end{array}$ \\
\hline
\end{tabular}

Meat Diet

DoGs

Braier, 1931

Braier, 1931

Total Fasting

10 days Braier, 1931

2nd day Braier, 1931

3rd day, with $B$. coli vaccine Braier, 1931 ...

Nitrogen Free Diet

4th day Braier, 1931

Minimum protein balance, with fat and starch diet Braier, 1931

Complete Diet

Braier, Morea, 1935

Nitrogen Free Diet

Braier, Morea, 1935
23.5

31

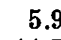

11.7

15.0

$\begin{array}{lr}9.5 & 9.3 \\ - & 15.6 \\ - & 21.1\end{array}$

6.1

$-\quad 10.0$

7.0

$-$

11.1

$$
\begin{aligned}
& -19 \\
& -24 \\
& -35 \\
& -24 \\
& -29 \\
& -39 \\
& -37
\end{aligned}
$$

- $\quad 29.1$

18.0
$-11$

\begin{tabular}{|c|c|c|c|c|}
\hline & $\begin{array}{c}17 \text { Dogs } \\
\text { Hypophysec- } \\
\text { tomized }\end{array}$ & $\begin{array}{c}5 \text { Dogs } \\
\text { Tuberal } \\
\text { Lesion }\end{array}$ & $\begin{array}{c}4 \text { Dogs } \\
\text { Thyroidec- } \\
\text { tomized }\end{array}$ & $\begin{array}{l}10 \text { Dogs } \\
\text { Control }\end{array}$ \\
\hline Fasting without phlorhizin.... & 0.25 & 0.36 & 0.25 & 0.36 \\
\hline Fasting with phlorhizin & 0.36 & 0.66 & 0.63 & 0.80 \\
\hline 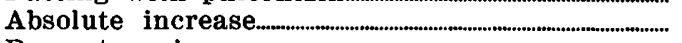 & 0.11 & 0.30 & 0.38 & 0.44 \\
\hline Percentage increase................ & 44 & 83 & 152 & 122 \\
\hline
\end{tabular}

$-29$

TABLE 5

Average Urinary Nitrogen in Dogs Under Different Experimental Conditions for Each Group (Recorded in Gm. N per Kgm. Body Weight per Diem)

Different Diets Plus Phlorhizin

\begin{tabular}{cccccc}
$\begin{array}{c}\text { Meat-Fed } \\
4 \begin{array}{c}\text { Hypophysec- } \\
\text { tomized }\end{array}\end{array}$ & $\begin{array}{c}\text { 4 Con- } \\
\text { trol }\end{array}$ & $\begin{array}{c}\text { 4 Hypophysec- } \\
\text { tomized }\end{array}$ & $\begin{array}{c}\text { 4 Con- } \\
\text { trol }\end{array}$ & $\begin{array}{c}\text { 4 Hypophysec- } \\
\text { tomized }\end{array}$ & $\begin{array}{c}4 \text { Con- } \\
\text { trol }\end{array}$ \\
\hline 1.37 & 1.56 & 0.30 & 0.76 & 0.33 & 0.73 \\
\hline
\end{tabular}

traperitoneally, produces not only a diabetic state, but also a marked increase in the total proteins, globulins, albumins and viscosity of the blood. ${ }^{37}$ Immediately after injection of the extract there is a decrease in the nonprotein $\mathrm{N}$ which lasts several hours. (Braier, confirming Teel and Watkins. ${ }^{419}$ )
GLUTATHIONE

Helen Maveroff, ${ }^{114}$ in nine hypophysectomized dogs, found an average decrease of 10 per cent in the glutathione of the red blood cells $(88 \mathrm{mgm}$. per cent as compared with $98 \mathrm{mgm}$. per cent in the controls). Injection of anterior lobe extract increases the glutathione in the red blood 
cells of normal, hypophysectomized and thyroidectomized dogs.114*

In the hypophysectomized toads (or after removal of the glandular lobe) when the asthenia is evident, the glutathione decreases in the muscles and more markedly in the liver; implantation of the glandular lobe prevents this decrease. ${ }^{104-111}$

\section{UROBILINURIA}

Hypophysectomized dogs eliminate $0.12 \mathrm{mgm}$. per day of urobilin in the urine (average of fifty determinations in six dogs). This is a normal amount (Royer, unpublished data). Injec-

\section{TABLE 6}

Urinary Excretion of Uric Acrd, Purine Bases and Allantoin

(Recorded in Mgm. per Kgm. Body Weight per Diem)

\begin{tabular}{ccc} 
Uric & Puric & Allan- \\
Acid & Bases & toin \\
\hline
\end{tabular}

Meat Diet

DoGs (Braier, 1933)

Normals

Hypophysectomized

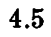

4.5
2.1

12.8

4.0

40.7

Nitrogen Free Diet

Normals

2.0

4.3

1.0

1.9

16.6

2.27

RATs (Braier and Morea, Unpublished)

Complete Diet

Normals

Hypophysectomized

3.5

2.5

14.2

14.0

83

Nitrogen Free Diet

Normals

Hypophysectomized

1.5

7.5

5.2

28

35

Urinary Excretion of Phosphorus in Fasting Dogs (GerschMAN, 1931)

(Recorded in Mgm. per Kgm. Body Weight per Diem )

\begin{tabular}{lccc} 
& $\begin{array}{c}\text { Meat } \\
\text { Diet }\end{array}$ & $\begin{array}{c}\text { Total } \\
\text { Fast- } \\
\text { ing }\end{array}$ & $\begin{array}{c}\text { Nitrogen } \\
\text { Free } \\
\text { Diet }\end{array}$ \\
\hline Normals & 46.5 & 17.7 & 15.1 \\
Hypophysectomized & 42.9 & 13.7 & 6.7 \\
\hline \hline
\end{tabular}

tion of $2 \mathrm{mgm}$. per $\mathrm{Kg}$. tetrabromosulphthalein in these animals is followed by a blood curve of normal aspect (Royer, unpublished data).

\section{INDOXYLEMIA}

This is normal in hypophysectomized and in thyroidectomized dogs. ${ }^{92}$

\section{PHENOLURIA}

Hypophysectomized dogs eliminate normal amounts of urinary phenol, when on a meat diet, but the excretion diminishes in fasting and more especially in protein fasting. ${ }^{34,35,104,105}$

\section{FAT METABOLISM}

Adiposity is a symptom of pituitary insufficiency in some species, but not in others. It forms part of the adiposogenital syndrome in man, due to lesion of the hypophysis or of the tuberal region. On the other hand in pituitary cachexia (Simmonds' syndrome) there is extreme emaciation. In hypophysectomized tadpoles the adipose organ persists. ${ }^{406}$ Adiposity is frequently observed after hypophysectomy in puppies, but occurs rarely in the adult dog. It is almost constantly seen, and in extremely accentuated form, in dogs surviving tuberal lesions for a few months. (Solari, ${ }^{133}$ confirming Camus and Roussy.) In the rat, adiposity is absent or may appear for a short time in a slight degree. Sooner or later these animals lose weight and become cachectic. (Morea, confirming Smith 1927-30.)

In hypophysectomized dogs there are slight variations in the total fats, fatty acids, and cholesterol of the blood, with a tendency toward a decrease. ${ }^{118,119,120 *}$ Munoz has seen that repeated injections of a diabetogenic anterior pituitary extract produce a marked increase in the total lipids of the blood (which has a milky aspect), as also in the fatty acids, cholesterol and phospholipids. $\dagger^{\dagger}$ This can be observed in dogs of both sexes, castrates, thyroidectomized and after section of both splanchnic nerves and extirpation of the lumbar sympathetic chain. Extracts of kidney and muscle prepared by the same technique do not have this activity. The liver in these animals also has a fatty aspect.

Dogs showing manifest adiposity owing to tuberal lesions have a normal specific dynamic action. (Solari. ${ }^{133}$ )

Raab has proposed a theory which has been favorably received. ${ }^{160,270,356,363,393}$ He believes that pituitrin and lipoitrin (which is found in both lobes of the pituitary and in the wall of the third ventricle) stimulate the tuber, from whence impulses travel by the spinal cord and the splanchnic nerves to the liver, increasing the fats in this organ and in the blood, owing to an increased mobilization of storage fat and consumption by the liver. A disturbance of some part of this complicated mechanism would cause an increase in fat storage and consequently adiposity. Munoz ${ }^{120}$ could not find any activity tending to decrease the blood lipids in posterior pituitary extracts, in spite of having injected as much as $100 \mathrm{mgm}$. per $\mathrm{Kg}$. of standard powder into dogs.

*Karlik and Robinsoin ${ }^{287}$ found hiperlipemia.

TThis increase in lipids is mentioned by Baumann and $\mathrm{Ma}$ rine, ${ }^{154}$ E. I. Evans, ${ }^{221}$ etc. 
KETONEMIA AND KETONURIA

Hypophysectomy considerably diminishes ketonuria; to 60 per cent of the normal in dogs under basal conditions $;^{129}$ to 28 per cent of that of the control animals in pancreatic diabetes $;{ }^{128} \dagger$ and to as low as 7 per cent of that of the control animals in phlorhizin diabetes during fasting. ${ }^{12 \downarrow}+$ (Table 7.) Tuberal lesions also pro- cant increase but the ketonuric activity of the extract was not altered by castration, extirpation of the adrenal medulla, lesion of the tuber or section of the splanchnic nerves with extirpation of the lumbar sympathetic chain. ${ }^{\mathbf{1 2 9}}$ (Table 7.) In hypophysectomized phlorhizinized dogs the extract raises the excretion of ketones to the same level as in the controls.

TABLE 7

Urinary Ketone Bodies (VAN Slyke, 1917), in Dogs Under Different Experimental Conditions (RIETTI, 1932-34)

(Recorded in Mgm. per Kgm. Body Weight per Diem)

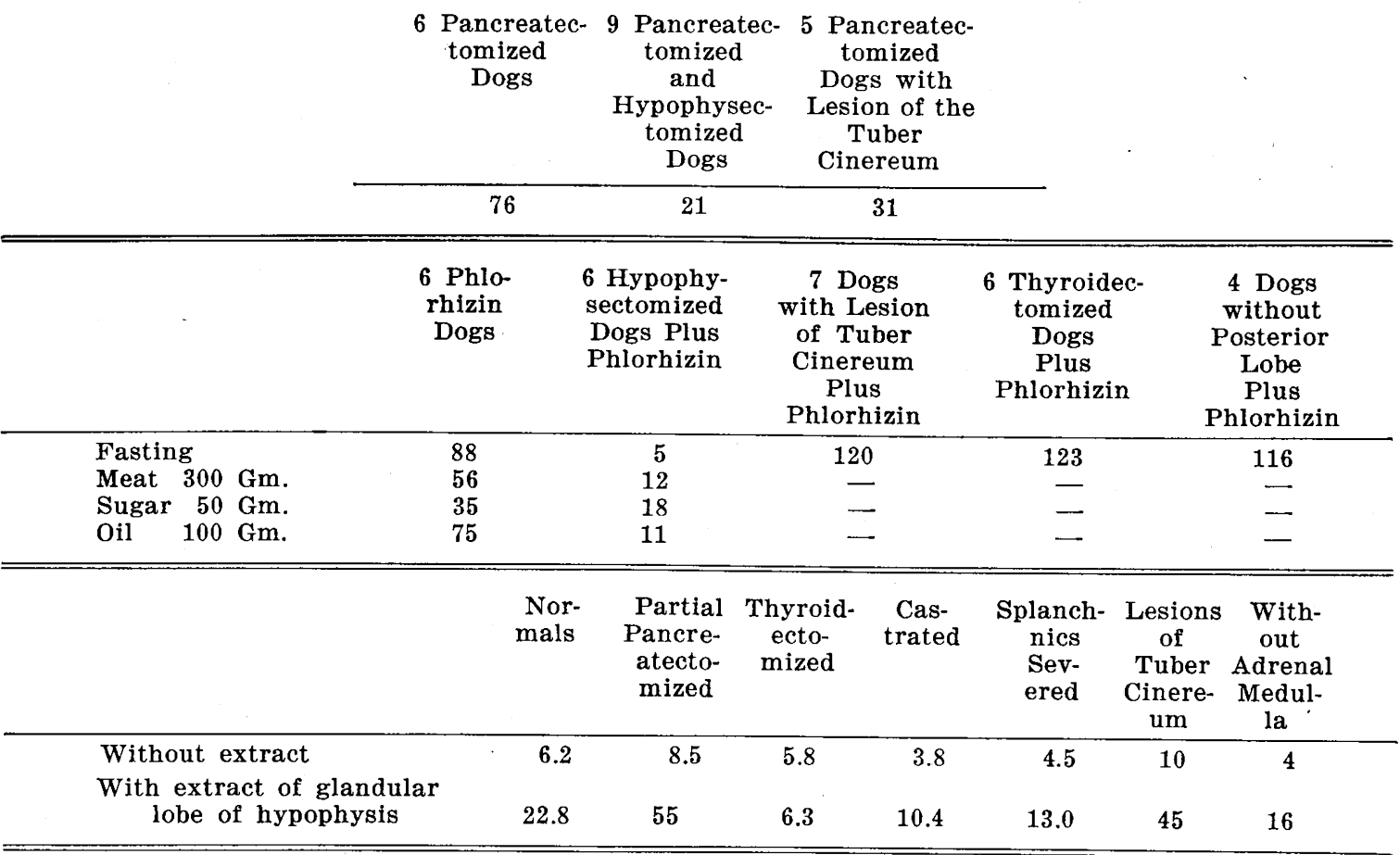

duce a small decrease in ketonuria in pancreatectomized dogs.

In hypophysectomized dogs on meat, sugar or fat diets the ketone elimination in phlorhizin diabetes is always smaller than in the corresponding controls. Sugar intake diminishes the elimination of ketones in the controls, but in the hypophysectomized there is a slight rise. Thyroidectomy, extirpation of the posterior lobe and lesions of the tuber do not diminish ketonuria as hypophysectomy does. ${ }^{128}$

The ketonuric activity of the anterior pituitary extract found in the rat by Burn and Ling, ${ }^{139,159,172,173,209,226,236,237,238}$ has been studied in the dog by Rietti. ${ }^{129}$ The total extract produces ketonuria in normal animals and this is more marked in partially panereatectomized and hypophyso-pancreatectomized dogs. ${ }^{66,69,70}$ In thyroidectomized dogs there was no signifi-

tLong and Lukens ${ }^{323}$ confirmed this in the cat. $\$$ Black ${ }^{158}$ confirmed this in the rat.
The increase in ketonemia produced by the anterior pituitary extract discovered by Anselmino and Hoffmann ${ }^{13 \tau}$ has been repeatedly confirmed. $137,138,139,162,219,238,246,258,259,272,310$, $338,339,340,360,393,402,403,414$, etc.

The ketogenic extract has been called the "fat metabolism hormone" by Anselmino and Hoffmann and "Orophysin" by Magistris, names that are not suitable and should not be used because they presuppose something which is not yet proved. According to Anselmino and Hoffmann, ${ }^{137}$ (cf. $246,{ }^{393}$ ) after a fatty meal the blood contains this hormone in quantities sufficient to produce effects when injected into another rat. This substance is not identical with the glycogen mobilizing one $e^{338,339}$ nor with the thyrotropic hormone. ${ }^{139}, 159$

Urine has a ketogenic and ketonuric activity. ${ }^{236,237,238,239}$ Methods have been described for the extraction and purification of this substance. both from the urine and the pitui- 
effects of the pituitary or even all of its influence on the fat metabolism by the action of a single ketogenic hormone. Evidently the anterior lobe of the hypophysis participates in the regulation of the daily amount of urinary excretion of ketone bodies; however it has not been definitely established whether its rôle consists in increasing their production or decreasing their consumption.

\title{
CARBOHYDRATE METABOLISM*
}

\author{
BY BERNARDo A. HOUSSAY, M.D.
}

\section{INTRODUCTION}

$D^{1}$ URING the last few years the important role which the pituitary plays in carbohydrate metabolism has been demonstrated. The essential physiological mechanism involves the anterior lobe, the posterior lobe having an accessory and much less important action. This is contrary to what has previously been supposed. The anterior pituitary lobe is probably, after the liver and pancreas, the most important regulator of carbohydrate metabolism. It would, however, be a grave mistake to imagine that the only metabolic function of the anterior pituitary is its action on carbohydrates. It holds a central position in the general metabolic regulation (water, iodine, protein, carbohydrate, fat, ketogenesis, etc.), as well as having essential and important actions on the endocrine system.

The alterations in the carbohydrate metabolism are especially marked in the toad, which is therefore the animal par excellence for its study. The changes appear or become accentuated about three weeks after hypophysectomy or extirpation of the principal lobe alone. At the same time symptoms of progressive neuromuscular asthenia develop, together with decrease in blood sugar and glycogen which causes death in four to eight weeks, survival for months being exceptional. Implantation of the principal lobe corrects these changes and prevents death. Similar symptoms are observed in hypophysectomized rats when they become cachectic. In dogs the compensation apparently is better, for they can survive for months or years in an apparently good state. However, they may present mortal cachexias or hypoglycemias. Despite their good appearance their metabolism is modified, as may be demonstrated by subjecting them to agents that induce hypoglycemia, or by producing diabetes, either by extirpation of the pancreas or by the administration of phlorhizin; these modifications affect particularly the metabolism of fasting animals.

Lesions of the tuber cinereum or of the hy*See footnote *, page 961 . pothalamus have a varying effect on the pituitary functions, according to the localization and extent of the lesion. In certain cases they cause marked inhibition of the anterior pituitary function which may be corrected by administration of the anterior pituitary lobe.

\section{THE BLOOD SUGAR IN HYPOPHYSECTOMIZED \\ ANIMALS}

Normal Blood Sugar. Many investigators have found subnormal blood sugar in hypophysectomized animals, dogs, ${ }_{126,279,290,293,294,333} \mathrm{rab}-$ bits, ${ }^{191,235}$ and in the pituitary cachexia of human beings. In reality, if the animals are properly cared for and are kept on an adequate diet, it has been found that the blood sugar remains within normal limits, ${ }^{*}$ in $\operatorname{dog}^{15-21,47-50,85,86,88 .}$ ${ }^{287}$ rabbits, ${ }^{298,}{ }^{379,}{ }^{380}$ cats, $^{337}$ rats, ${ }^{362}$ and amphibians. ${ }^{29,}$ 78, 93, 94, 401, 437

However, one of the most salient characteristies of pituitary insufficiency is the tendency to hypoglycemia during fasting, which becomes manifest after a few hours.

Hypoglycemias. Hypophysectomized animals readily become hypoglycemic and may present grave symptoms, frequently terminating in death. Treatment with sugar produces spectacular improvement but must be initiated early and repeated frequently. Good results from injection of adrenalin or postpituitary extracts are much rarer.

The hypoglycemias may be elassified according to their cause as postoperative, spontaneous, due to fasting, eachexia, insulin, phlorhizin, secondary, etc. After operation ${ }^{252,268,342,431}$ or during the evolution of pituitary eachexia 146, 174, 251, 257, 325, 326, 327, 361, 366, 379, 380, 404, 432 hypoglycemia and hypoglycemic crises frequently occur. " "Spontaneous" hypoglycemia, observed first by Wilder ${ }^{432}$ in man and by Houssay and Biasotti ${ }^{56-60}$ in dogs, has since been seen in dogs, ${ }^{56-60,187,200,290}$ rabbits, ${ }^{191,}{ }^{431}$ guinea

*In 20 hypophysectomized dogs we found 0.097 per cent in the morning and 0.1 per cent $2 \frac{1}{2}$ hours after a meat meal; in 20 controls the figures were 0.105 per cent and 0.109 per cent respectively. 